\title{
The New Miss India: Popular fiction in contemporary India
}

Miss New India is the title of one of many contemporary novels for a woman readership that are to be found in bookshops across India. From the shiny Crossword chain of bookshops in the big city malls, to dusty side road bookstalls, these novels will be found alongside manuals of management, guides to business success, the novels of Ayn Rand, and, disconcertingly, copies of Mein Kampf ${ }^{1}$. These texts are being bought up by a new 'Young India', in the phrase of the best-selling novelist Chetan Bhagat, who exhorts his readership: 'We need to get rich, and fast ...' (Bhagat, p.129). For Bhaghat, 'Young India' is asserting itself as aspirational and entrepreneurial, the generation who grew up in the wake of India's secondgeneration economic reforms and are now urged to make the most of the opportunities of globalization.

In 2003, Sunila Kale explained that: ' . . f four consecutive democratically elected governments in India in the 1990s were able to pass important legislation that carried India far from its historical moorings in centralized planning and towards a market-oriented system'(Kale, p.210). That market-oriented system demanded new kinds of workers, and a new form of entrepreneurial culture in India. The journalist Akash Kapur has described his return to India from America in 2003 to find change manifested in the bookshops: 'Bookstores were filled with titles like India Arriving, The Indian Renaissance and India Booms' (Kapur, p. 4) One of the titles that Kapur might well have found is the Indian published manual Take Me Home, subtitled: 'The inspiring stories of 20 Entrepreneurs from small-town India with big-time dreams'. This is a collection of stories of Indian business people who have made a success in the city and returned to their home towns in triumph. The editor is a woman, Rashmi Bansal, who is described in her author profile as 'a writer, entrepreneur and youth expert. . . the author of five bestselling books on entrepreneurship . . . a motivational speaker and mentor to students and young entrepreneurs'. Of her twenty stories, only one is centred on a woman, her entry tellingly titled 'We Shall Overcome'. In her introduction to these 'inspirational' stories of entrepreneurship, Bansal writes:

This is the new India, the 'real India', the consumer every marketer and every soap opera wants to reach. They have overpowered the metros with their numbers, with 
their hunger. To be something, to do something. Through education, through aspiration, through pursuit of work.

They come to metro cities, in search of opportunity. . . . For there is a small revolution taking place in small-town India. A new breed of entrepreneurs who are changing old equations and assumptions. (Bansai, p. vii)

Novels and self-help manuals offer fictional or didactic narratives of this 'new breed', in tales of sexual and financial ambition which are symptomatic of the rapid changes in Indian culture and communities. This is a 'new India' in which the landscapes and people are transforming. Kapur describes the road leading to his childhood home outside Chennai in South India, which he sees as:

... a showcase of the new India. The farmland has become fertile terrain for steelframed and glass-panelled office buildings. These buildings house the technology companies driving India's economic boom - the Yahoo!s and PayPals and Verizons that have rushed into the country over the last couple of decades, but also local upstarts like Infosys, Satyam and Wipro that have for the first time put India on the map of global business.

Employees of these companies ... are the footsoldiers of India's surging economy; with their confidence, their enthusiasm, their willingness to work long hours, they are driving the emergence of a new nation. (Kapur, pp.2-3).

It is these 'footsoldiers' and environments which provide the characters and settings for the popular fiction of the New India; their protagonists are the 'Affluent Urbanites', in Pamela Shurmer-Smith's phrase (Shurmer-Smith, p.29), young people who belong to the big city. Kapur looks on at the rapid expansion of cities such as Bangalore ${ }^{2}$, Chennai, Hyderabad and Mumbai with mistrust:

. . . cities that heaved with ambition and entrepreneurship and opportunity . . selfconfident, brash and unshakably optimistic. The twenty-first century had come to them like a party; a celebration of the nation's potential; they embraced modernity unhesitatingly. (Kapur, p. 39) 
The heroes and heroines of Indian popular fiction have no such qualms, but appear to wholeheartedly embrace the new modernity, they are characters who embody self-confident optimism and ambition.

As India relaxed regulations on foreign investment and (partially) opened up to global capital, so new forms of service industry and new kinds of work developed, most notably around information technologies, as Daya Thussu puts it:

The deregulation, liberalization, and privatization of the 1990s ... ushered in a rapid transformation in India's service industries, particularly in information and communications technologies, signifying the transition of large part of India's predominantly agricultural economy into a knowledge-based, globalizing economy. (Thussu, 2013, p. 101)

The call centre is the emblematic icon of this transition in the Indian economy and workforce, an emblem of an urban and global workplace, staffed by educated and ambitious young people. As Shashi Tharoor explains:

The call centre has become the symbol of India's newly globalized workforce: while traditional India sleeps, a dynamic young cohort of highly skilled, articulate professionals works through the night, functioning on US time under made-up American aliases, pretending familiarity with a culture and climate they've never actually experienced, earning salaries that were undreamt of by their elders (but a fraction of what an American would take) and enjoying a lifestyle that's a cocktail of premature affluence and ersatz westernization transplanted to an Indian setting. (Tharoor, pp. 18-19)

Bhagat's best-selling 2005 novel One Night @ the Call Center established the call centre as a site for fiction, and IT workers as characteristic of ambitious and modern young Indians. His 2004 novel 5 Point Someone (which became the 2009 hit film 3 ldiots) is set in the Indian Institute of Technology, and led to numbers of imitators keen to emulate the combination of aspiring young students and workers, sexual awakening and youthful ambition that are the stuff of Bhagat's novels. These established a genre that Dawson Varughese has described as 'Youth narratives and 'young India" (Dawson Varughese, p. 200). The most successful novels chart the coming of age of young men, but there is also a feminised version of this narrative 
that is to be found in romance fiction for a female readership, a genre that Dawson Varughese puts into the sub-category 'Chick-Lit' (Dawson Varughese, p. 201).

Tharoor's description of an 'ersatz westernization transplanted into an Indian setting' is precisely the environment that Anjali Bose ${ }^{3}$, the Miss New India of Bharati Mukherjee's 2012 novel, seeks and finds as she leaves her small town family home, fired with the ambition to work in a call centre: 'The call centres, luring thousands of young people from all over the country, people like her, the new people' (Mukerjee, p. 12). Anjali is unusual as a heroine of this genre of fiction, as a young woman who leaves her small town and family to make her own way in the city of Bangalore, the 'beating heart of India's IT industry' (Rahdhakrishnan, p. 26). She is prepared to lie, cheat and steal in order to achieve her ambition, and to assert her independence from her family; Anjali embodies what Kapur has described as: 'the energetic (and often ruthless) ambition of a new generation' (Kapur, p. 6). Anjali styles herself with a Westernised version of her name, Angie (a trope that is a regular feature of these novels); the big city offers new possibilities for reinvention of the self, a break with family and fixed identities:

No one in Bangalore seemed to be stuck with a discernible identity ... She could be anything she wanted... Who do you want to be?

Bangalore doesn't care. Bangalore will accommodate any story line. She could eliminate her parents and her sister. (Mukherjee, p. 95)

Anjali is identified at high school as one of the dynamic youth of the New India; as her American school teacher tells her: 'You have the spark - don't crash and burn. India is starting to wake up. India is a giant still in its bed, but beginning to stir. It's too late for me, but India is catching fire (Mukerjee, p. $x)^{\prime}$.

Angie's first encounter with Bangalore takes place in a coffee shop, another emblem of a new globalised India, where she is surrounded by glamorous young people, all sporting similarly Westernised names: 'Most of the small round tables were occupied by large groups of noisy patrons her age, dressed, like her, in jeans and T-shirts ... young men and women were plugging away, doing work on laptops' (Mukherjee, p. 85). Anjali is one among many in a workforce of 'low cost, high IQ, English speaking brain power' (Business Week 2003, quoted 
in Thussu, 2009,p. 18). There is a real life counterpart to Anjali Bose in Kapur's account of the twenty-one year old Selvi, who works in a call centre for an American credit card company. Selvi is, like Anjali, originally from a small town, Kapur's description reads much like Mukherjee's characterisation of Anjali, : '. . . she was ambitious. . . There was something determined, even ferocious about Selvi' (Kapur, p. 51). Just like Anjali, Selvi is taught to perfect an American accent, and inducted into the culture of American consumerism.

If Anjali's determination to become a call centre worker might seem a limited ambition, work in any area of IT is a relatively privileged position in India; as Smitha Radhakrishnan puts it:

Indian IT professionals are privileged through their ability to imagine and live out personal and professional lives in multiple places... This privilege stems from their dominant position in the global economy as well as their material and symbolic privilege within India. The privilege of India's new transnational class is embedded in national/domestic hierarchies, global capitalism and Indian class structure.

(Radhakrishnan, p.25)

As a young woman, Anjali is on the wrong side of the gender hierarchy, and is in need of two male mentors. The first is her teacher, an American who came to India in the 1960s, who lends her the money to escape to Bangalore - Anjali considers seducing him, only to find that he is gay. Her guide to the city is Mr GG, a property developer, who is literally building a new India and who introduces her to a the urban world of global corporate logos: "her first Starbucks, her first Pizza Hut, and then a Radio Shack, all wondrous logos, with expansion plans and corporate cultures..'. Mr GG, like the coffee shop IT workers, is a member of the 'transnational class'; his consulting company is a 'Swiss-Canadian collaboration, fifty per cent locally financed' (Mukherjee, p. 100). Mr GG confidently asserts that while India is in need of global investment, global corporations require the skills that India can offer. He is insistent that India can manage global capitalism on its own terms: 'Every business in the world is outsourcing, Without us, the world would collapse ... we would collapse without international collaborators. ... Then they'd collapse without us' (Mukherjee, p. 101).

This is a generation for whom British colonialism is now an irrelevance; Anjali's contact in Bangalore is Mrs Minnie Bagehot, an elderly Anglo-Indian who, along with her house in 
Whitefield ${ }^{4}$, is a tattered vestige of the days of the Raj, 'stuck-in-the Raj Minnie Bagehot' (Mukherjee, p. 120). Once a grand British residence, Bagehot House is now a hostel for young women call centre workers, an image of transition from the colonial to the global. Mrs Bagehot is summarily despatched in the narrative, murdered by a gang of looters and her servant who strip the house of its battered antiques, a victim of a ruthless city which no longer has any deference.

The novel ends with Anjali returning to her home town and high school in triumph as a newly promoted debt-recovery agent; her return reads much like the 'inspirational' case studies of Bansal's collection. The small town to which she returns has also transformed, poised to become 'a future IT magnet' (Mukherjee, p. 325). Anjali is one of a ruthless new generation who has seduced, stolen and lied her way to a limited success. The narrative does not in any way criticise her methods but instead celebrates her ambition and work ethic: 'She'd gone to fabled Bangalore and worked hard' (Mukherjee, p. 324). While Anjali may end the novel triumphant, the novel ends with the haunting image of the mutilated body of her teacher's male lover, broken in an attempt to become an ideal of contemporary Indian femininity.

The cover of Aditi Kotwal's Draupadi in High Heels (2013) shares much of the iconography of the Western 'chick-lit' novel with its neon pinks and stiletto shoes, here worn by a woman in a sari. The title brings together contemporary fashion with a heroine of the Mahabharata; the negotiation between Indian and Western cultures is the real subject of the novel. The heroine, Deeya Panchal, is the daughter of a newly wealthy India; an aspirational figure, she is among the 'Very Rich' of India (see Shurmer-Smith, p. 31), her lifestyle and wardrobe described in the language of international fashion and travel magazines. The world that Deeya inhabits is that of the gossip columns; her family is exceptionally wealthy, she is the daughter of a steel magnate: 'not only one of the richest men in Mumbai, but also the whole of India' (Kotwal, p. 9). His daughter has been educated at a 'Swiss finishing school', she is dressed in Dior and diamonds, flits between London, Italy and Mumbai and is pursued by Bollywood and sporting heroes. Deeya does work, she runs a boutique (subsidised by her father) which stocks both international and Indian 'select couture designers', in a synthesis of Western and Eastern. To her friends she is known as 'Dee', in a Westernisation of her name. 
The apparently independent, well travelled and cosmopolitan Deeya nonetheless continues to live at home with her parents; their extravagant house is another synthesis of tradition and modernity, East and West: 'a magnificent two-storey building ... We have retained most of the beautiful old design and juxtaposed it with modern décor ... You don't find palatial houses like these any more in Mumbai' (Kotwal, p. 35). Safely enclosed in her 'magnificent' mansion, and chauffeured to the best hotels and restaurants of Mumbai, for Deeya, the poor exist only as a charitable opportunity: 'My family was known for its charity and philanthropy, and my parents had instilled those values in us (Kotwal, p. 84)'. Like a Victorian Lady Bountiful, she donates stationary to an orphanage, there she encounters the hero, each approvingly acknowledging the other as a philanthropist, and so proving their compatibility with the recognition that they share both wealth and a sense of social responsibility. If dispensing stationary will do little to address the structural inequalities of India, it does serve to alleviate Deeya's conscience. Thussu has pointed to the limitations of the generosity of the wealthy in the new Indian economy: 'Predominant sections of these upper strata of Indian society - the 'Westoxicated elite'. . . have scant respect for the masses, or for any meaningful attempts toward an inclusive and equitable society'. (Thussu, 2013, p. 179).

Deeya's family is undoubtedly part of this 'Westoxicated elite', but for all their Western sophistication, the family still holds firmly to Indian traditions of family, gender and religion. Deeya is a much protected daughter; in London, she confides that she 'would never have been allowed to take the tube back home in Mumbai' (p. 9). Her father, though Harvard educated and clad in Armani, consults a guru, and is described by his daughter as: 'deeply religious, (he) makes no decision unless Baba Dinanathhi approves'(p. 10). In the course of her own romantic entanglements, the heroine too will come to appreciate the wisdom of the family guru.

The novel offers a compromise between independent romantic choice and an arranged marriage. While Deeya asserts her modernity: 'Arranged marriages were passé in our family ... How could they expect me to go for an arranged match in this day and age?' (Kotwal, p. 25), the face-saving solution is that her parents organise a grand party packed with eligible and approved bachelors, in a chapter titled, with a nod to Vikram Seth's 1993 novel A Suitable Boy, 'Finding a Suitable Boy'. The most 'suitable' men among the potential suitors 
are a family of three brothers, heirs to an industrial fortune and known to Deeya since childhood: 'the most popular boys in school. All of them excelled in whatever they put their mind to' (Kotwal, p. 20). Another potential hero is the 'billionaire' head of 'SunChip Tech', MIT educated, he is a self made man as the adopted son of the same family, who appears to be less 'suitable' because he seems to be of a lower caste. In a deliberate echo of Pride and Prejudice, Deeya is misled into insulting him at her party; throughout the narrative it is unclear whether he is a Darcy or a Wickham figure, whether he will prove to be a hero or a cad, an Indian aristocrat or young man on the make.

One of Deeya's childhood friends is studying the Mahabharata for his PhD in Oxford, and as a wise counsel, insists that she read it. The story of Draupadi, the 'legendary beauty' and wife of five brothers, runs as a thread throughout the novel, paralleling the romantic exploits of a contemporary young Indian woman with those of a Mahabharata heroine. Draupadi's story is also taken up by the family guru, who finally points her towards the right man. It transpires that the IT billionaire and adopted son is both high caste and of European lineage, and so is an appropriate choice for a family with 'stature in society and ... immense wealth' (Kotwal, p. 149). The Mahabharata and the guru between them finally determine the couple's future and resolve the contradictions between modernity, new wealth and family and Hindu tradition.

Anuja Chauhan's 2013 novel, Those Pricey Thakur Girls also offers a version of Pride and Prejudice, in its narrative of five daughters in search of a happy marriage; set in the recent past (an unspecified period sometime in the late 1980s and so before economic deregulation), the romance plot is set against a background of government corruption. The name 'Thakur' establishes the family as high caste, and the daughters (even those who are married) are known to the community by their family name. Their father is a retired judge, his father a brigadier in the Indian Army, and the family inhabits a grand bungalow which is threatened by a housing development. He and the bungalow are emblems of a past India that is threatened by an encroaching modernity; new technology is invading the domestic sphere as his grandsons bring home a computer: 'a large squat rectangular grey blob that looks like an ugly electric oven' (Chauhan, p. 33). 
The novel begins, much like the opening of Anita Desai's Fasting, Feasting, with the patriarchal judge relaxing in his walled garden and enjoying the 'tea and snacks that have been laid out' by his wife. He drives a black Ambassador car, which like his bungalow, is now showing its age. The family finances have been depleted by the costs of the weddings of the three eldest daughters. The judge displays the same quality and accoutrements that the essayist Pankaj Mishra described in his account of male middle class civil servants in India in 2006:

Dignity, and how to hold on to it: that was what preoccupied these men ... the dignity whose emblems included the bungalows, the white cars . . . the dignity that came out of asserting one's distance from everything tainted by the ordinary misery and degradation of India. (Mishra, pp. 39-40)

The judge is concerned to protect his daughters from that 'ordinary misery' and to ensure that those who have married thrive and those that are not will marry well. As the novel opens, three of the daughters are married and are perilously close to misery. Between them, the sisters represent a range of female experience and the possibilities for (heterosexual) relationships in India. Angini, the eldest and ' family beauty' is married to a chilly husband and is unable to conceive a child, the second is married to a failed entrepreneur who is constantly embroiled in dodgy schemes. The third is the black sheep of the family, who rejected her parents' choice of husband and eloped with a 'shady American-Estonian' the night before her wedding. Each daughter (in different ways) is challenging the traditional role of the Indian wife, embodied in their own mother, Mamta. Like many of the parents in these fictions, the mother is seen as holding on to old superstitions, she consults a family astrologer, who predicts 'fortune, fertility and fame' (Chauhan, p. 4) for the fourth daughter, Debjani.

The central focus of this novel ${ }^{5}$ is on Debjani who, as the novel opens, is about to take up her post as an English newsreader on Indian television. Despite being highly educated, and succeeding in 'clearing two rounds of country wide auditions ... to emerge triumphant as an English newsreader on India's one and only television channel' ((Chauhan,p. 4), Debjani continues to share a bedroom with her youngest sister in the family home. The two younger daughters dress in Western style at home, Debjani is 'relaxed in denim cut-offs and baggy T-shirt', while Eshwari sports 'a 'short blue skirt' with her school uniform (Chauhan,p. 
5), but Debjani wears a sari for her work as a newsreader, and formal family events require traditional dress. All the sisters have Bengali names, but their family nicknames are Western; Anji, Deb. Their cultural references are informed by both India and the West, they read Western fashion magazines, watch American television, but at a point of intense romance for Debjani it is Hindi films that frame the experience: 'Warning bells, straight out of the climatic temple scene in a Hindi movie are ringing madly inside her head' (Chauhan, p. 129).

Like Elizabeth Bennet and Deeya of Draupadi in High Heels, Debjani initially takes against her love interest and is appallingly rude to him at a social event. The hero is an investigative journalist, but, importantly, is also the son of her father's friend and card partner, a Brigadier. While Debjani's romance is a love match, the marriage must be formally approved by both sets of families, and is finally arranged by her father; as the hero's mother explains: 'Thakur is experienced, he has married off three girls. He knows how to play this game ...' (Chauhan, p. 148).

If the setting in a pre-liberalization era is nostalgic for a lost India, there is a strong sense in the novel that modernization is necessary. The sub-plot of government corruption suggests a need for reform, there is frustration at the single government television channel, and the sisters welcome the prospect of becoming Western consumers, as Anjini puts it: 'I'm all for opening up. We'll get Coke in India, imagine that!' (Chauhan, p. 210). Nonetheless, there is also a clear unease at the rush towards liberalization; both the judge and the hero express the fear that economic deregulation will lead to a divided India:

... all this excitement round the opening up of the economy is misplaced ... it's going to split the country even more sharply, the rich will get richer and the poor poorer and. .. we will end up with two entirely separate Indias - a tiny one that will be a clone of the first world and a massive one that will be sitting in the gutters (Chauhan, p. 210).

Poised at a moment of transition, as a high caste family whose status was formed in the old India, the Thakurs are unclear as to which side of the divide they will find themselves.

Itisha Peerbhoy's 2014 Half Love, Half Arranged is described on the front cover as 'chaotic, funny and bold.' That boldness is evident in the mild profanities which open the novel 'Oh Crap! ... Goddammit' (Peerbhoy, p. 1), while this may not seem particularly shocking to a Western liberal reader, the novel is courageous ${ }^{6}$ in its sympathetic representation of the 
heroine's lesbian sister, in an India where homosexuality remains illegal and taboo within most families. Like Dupraya in High Heels, the title exemplifies a tension between Indian tradition and contemporary Westernisation for young women. The heroine, Rhea, is another infantilised daughter; although she begins the novel as a thirty year old woman leading a team of IT workers, she still lives at home and is not over perturbed when she loses her job because of her distraction over her romantic life. Her bedroom has curtains printed with rainbows and mice, her walls are covered with 'all the posters from my hormonal teen years . .. Michael J. Fox, New Kids on the Block, Patrick Dempsey and Bon Jovi' (Peerbhoy, p. 235). Rhea may swear, smoke, drink and use Facebook with her friends, but she knows not to admit this outside her friendship group, at home she is a dutiful daughter. The tension between Western liberalism and Indian family values is represented as a source of perpetual confusion for a contemporary young woman.

The heroine's parents belong to an earlier generation of Indian modernity and liberalism, her mother is a doctor who 'wears Nikes, with her salwar-kameez' (Peerbhoy,p. 3). Her father is an upwardly mobile migrant to the big city 'who had left Dhi Punjab with only six bush-shirts to his name, but who now owned a metal-pipe factory and supply unit ... and golfed with rich people' (Peerbhoy,p. 3). For all their expressed liberalism and modernity, Rhea's family still hold with the idea of arranged marriages, and she herself believes marriage to be her way out from the family home: 'I'm not supposed to be still living at home. I'm supposed to be married, making things like rocket-and feta-salad with my husband' (Peerbhoy, p.4). The novel regularly references Rhea's 'Bubbles Auntie' as a nightmarish figure of the older, unmarried woman; despite the fact that she is college educated and works in film production it is her single status that defines her: 'Bubbles Auntie is 'Unfulfil' (sic) - that thing that happens to a woman when she gets everything in the world except marriage .. the future is not exactly rosy for an unmarried girl in a middle -class Punjabi family' (Peerbhoy,p. 42).

The novel charts a series of arranged encounters with 'a suitable boy' which become increasingly organised and official, from the first set up with the son of a family friend, to formal dinners, through to dating web sites and finally a professional marriage broker; as her mother finally despairs 'of this friend recommendation, net-shet. We need a professional' (Peerbhoy, p. 88). The plot is driven by Rhea's exploration of a range of different kinds of 
contemporary Indian masculinity, in search of that husband. Her first encounter with the handsome Vyash is set up by both sets of parents; while they each express reservations about this way of meeting, both accept it; he is divorced, she is thirty. Neither is the ideal bride or groom; the matchmaker trades the caste, profession and good looks of the groom against the age, attractiveness and family of the prospective bride, Rhea's age and weight count against her, so that: 'maybe we have to try out of caste' (Peerbhoy, p. 91). If caste is rarely directly mentioned, there is a distinct undercurrent of prejudice against darker skins; while this is largely displaced onto the parents' generation, who consistently make comments about the complexion of any eligible suitor. Rhea herself sees 'fairness' as a quality of the love object. She rejects one of her prospective suitors because of his skin colour: '. . we would have dark children and my mother would be rubbing them down with gram flour till their skin peeled off or they turned albino' (Peerbhoy, p.79).

What is distinctive about Rhea as a heroine is that she does have sex with men, her parents' idea of 'suitability' depends on the man's income, professional status, family and caste, but in the twenty first century it is acknowledged that sexual compatibility is a requirement of a partner for a modern young woman. Throughout the novel, Rhea's romantic partners are compared with her close male friend from college, Arf. In the conventional romance narrative Alf would appear to be the hero, recognised as such by the reader but overlooked by the heroine until the end of the novel. The narrative is persistently self-referential and knowingly aware of the conventions of genre romance, Rhea refracts her erotic encounters through the lens of the romantic novel:

... your average Mills and Boon woman would barely know the guy. Or he'd be her boss or something and she'd have to sleep with him or she'd lose her job ... Then she would be seduced in a way very similar to this, except it would be in his mansion and she would have got there in his private jet. (Peerbhoy, p.70)

By the time Rhea does recognise her feelings for Arf, as Mills and Boon would predict, he has retreated into spirituality and an ashram. The novel does hold out the possibility of a romantic partnership chosen by the woman, based on friendship and the shared experience of college, but it is finally the most traditional form of courtship that prevails. It is the matchmaker who provides the husband and it is her father's advice she takes in choosing among the men. The matchmaker finally produces her 'flagship product' ((Peerbhoy, p.70), a 
half Indian, half Norwegian businessman who lives in America (like Deeya's billionaire, he boasts a European heritage); as Rhea recognises, this is a status husband: 'the truth was, my parents' cachet would go up several notches if I married a half-white man and moved to America' (Peerbhoy, p. 208). It is significant that the novel ends with an account of the women friends scattered across a diaspora, to Canada and the UK, while Rhea herself moves to America; only one among the group remains in India. One friend finds 'the real Punjab in the UK' (Peerbhoy, p. 270); India is no longer contained by geography.

These narratives are popular genre fiction, they allow their protagonists positive resolution, in which romance and financial success are crucial. But there is an uneasiness in reading of conspicuous consumption and the rewards of ambition in the context of an India in which millions of citizens remain in poverty, a poverty that the chill winds of global capitalism will do little to address. As Thussu put it in 2013:

At a time when neoliberalism has created new modernity in shopping malls, Bollywood films, and fashion shows, nearly 300 million Indians live in abject poverty and deprivation. These social realities coexist in an upwardly mobile India, whose corporatized pro-American government, businesses and dominant sections of media and academia tend to ignore such stark inequalities. (Thussu, 2013, p. 13)

The narratives make only oblique references to caste, to poverty, to the limited availability of education. They are located almost entirely in the emergent middle class of the new India, their characters are among the 'upwardly mobile' of India, and they inhabit the world of shopping malls and corporate business.

Kapur, writing in 2012, like the father and hero of Those Pricey Thakur Girls, expresses an ambivalence about the changes then sweeping India:

... over the last decade or two, the narrative has changed: now people write stories about Indian upliftment, about a nation on the move, emerging from the shadows of poverty into the glitter of twenty-first -century prosperity . . . I could understand why people were tired of hearing about misery. I could understand why they wanted happy stories. Still, I couldn't help feeling that we were replacing the old cliché with a new one - that the new, happy narrative was just as simplistic as the old, depressing one. (Kapur, p. 171.) 
These narratives are those 'happy stories', but they are not entirely simplistic. The generic conventions of the romance novel require a happy ending, but there are jagged and uncomfortable edges in the resolutions of these novels. The broken body of Peter's lover in The New Miss India, the diaspora of Indian women in Half Love, Half Arranged, the unrealised possibilities of Draupadi in High Heels and the political corruption that motors the plot of Those Pricey Thakur Girls, these are indicators that the race towards a newly globalised and neo-liberal India is not entirely embraced by all of India. The novels are not without their contradictions, while the central protagonists may find love and financial reward, their pages are full of those who have not.

Chetan Bhagat credits his education for his own success' IIT did for me what liberalization did for India - created opportunities and changed me forever'( Bhagat, p. ix). The young woman of these novels do not have the same opportunities; while they are educated, it is generally not beyond high school or finishing school, while they may work, this is subjugated to the search for a partner and relinquished on marriage. It is only Anjali of Miss New India who demonstrates anything like the same ambition as Bhagat's male protagonists. All the other heroines experience a conflict of loyalty between their desire for independence and the demands of the 'joint' family, described by Deosthale and Hennon:

... a strong interdependency with more emphasis on the family than the individual, with the family seen as fulfilling many needs of the individual. This view emphasizes the importance of patrilineality and of the familial and fraternal relationships while deemphasizing the spousal and parent-child relationships ... Typically the eldest male is the most powerful ...Women often exert authority covertly through their husbands (Deosthale and Hennon, p. 298)

These are the characters of these novels, mothers who can only exert power through their husbands, daughters who defer to their fathers. The recurrent references to Pride and Prejudice in these novels underscore how central marriage and courtship are to the narratives of young women's lives still in the $21^{\text {st }}$ century, daughters continue to be used as a means of family alliances and merged fortunes and, with very few exceptions, themselves see marriage as their proper destiny. 
These novels bear out Radhakrishnan's research; her study of women IT workers in India points to the contradictions of the new 'transnational' class and she argues that those contradictions are particularly acute for women:

The culture of this class is full of ostensible contradictions: it embraces individuality, development, and change but holds fast to specific ideas of tradition and change; it encourages women to be 'empowered' but places specific limitations on such empowerment; it claims inclusivity by thinking of itself as 'middle class' yet the boundaries in terms of who enters into its fold are remarkably limited. (Radhakrishan, p. 3)

In 2012, Bhagat, , on behalf of 'Young India' asserted the need for a new way of thinking and a departure from the old ways:

... Our enemy is the old school of thought, or rather, the people who defend the old school of thought. They do this in the name of antique India policies, culture and values ... And to defend themselves and their ways, they don't mind crushing the aspirations, ideas and talent of an entire generation (Bhagat, p. 129).

For the 'new Miss Indias' of these novels, it is not that this 'antique' Indian culture and values are being promoted by an enemy, instead, the 'old school' is represented by their much loved families, particularly their fathers, their values largely shared by the young heroines. The weight of Indian tradition - whether Hindu or Muslim - is shown to be very heavy indeed. In these narratives, the pull of family, religion, caste and tradition continue to exert a very powerful force; the burden of continuity and tradition continues to rest with the women.

Notes

Bansal, Rashmi Take Me Home: The inspiring stories of 20 entrepreneurs from small-town India with big-time dreams. Chennai: Westland Ltd. 2014

Bhagat, Chetan. What Young India Wants: Selected Essays and Columns New Delhi: Rupa Publications India, 2012 
Dawson Varughese, E. Beyond the Postcolonial: World Englishes Literature Basingstoke: Palgrave Macmillan, 2012

Deosthale, Duleep C. and Hennon, Charles B. 'Family and Tradition in Modern India' in Hennon, Charles B. and Wilson, Stephan M. (eds.) Families in a Global Context New York: Routledge. 2008, pp.295-322

Desai, Anita Fasting, Feasting London: Chatto and Windus, 1999

Kale, Sunila. 'The Political Economy of India's Second-Generation Reforms' in ed. Ganguly, Sumit, India as an Emerging Power London: Frank Cass, pp. 207-225

Kapur, Akash. India Becoming: A Journey Through a Changing Landscape London: Penguin 2012

Mishra, Pankaj. Temptations of the West: How to be Modern in India, Pakistan and Beyond London: Pan Macmillan, 2006

Kotwal, Aditi. Draupadi in High Heels New Delhi: Penguin Books India, 2013

Peerbhoy, Itisha. Half Love Half Arranged Haryana: Penguin Books India, 2014

Radhakrishnan, Smitha. Appropriately India: Gender and Culture in a New Transnational Class Durham, North Carolina: Duke University Press, 2011

Shurmer-Smith, Pamela. India: Globalization and Change London: Arnold, 2000

Tharoor, Shashi. The Elephant the Tiger and the Cellphone: Reflctions on India in the $21^{\text {st }}$ Century New Delhi: Penguin Books India, 2007

Thussu, Daya Kishan. 'Why internationalize media studies and how?' in ed. Thussu, Daya Kishan Internationalizing Media Studies London: Routledge, 2009 pp. 13-31

Thussu, Daya Kishan. Communicating India's Soft Power: Buddha to Bollywood Basingstoke: Palgrave Macmillan 2013

\footnotetext{
1 The Daily Telegraph reported in 2009 that: 'Sales of the book [Mein Kampf] over the last six months topped 10,000 in New Delhi alone ... the surge in sales was due to demand from students who see it as a self-improvement and management strategy guide for aspiring business leaders, and who were happy to cite it as an inspiration' (The Daily Telegraph, 20 Aprill, 2009)

${ }^{2}$ The name of the city was officially changed to Bengaluru in 2014, but journalists and novelists tend to continue to refer to Bangalore

${ }^{3}$ The surname Bose indicates that Anjali comes from a Bengali Hindu family, and belongs to a caste that derives from scribes
} 
${ }^{4}$ Whitefield is so named because it was once a suburb inhabited by the British and by Anglo-Indians, a number of whom remained after independence. Once a suburb of the city, it has now been incorporated entirely.

${ }^{5}$ Chauhan plans a series of novels about the Thakur family, which will follow the narratives of the other sisters

${ }^{6}$ Quite how courageous is evident from the novelist Perumal Murugan who withdrew his novels from publication and declared himself dead as a writer after Hindu nationalist protests in Tamil Nadu.

(www.Guardian.com, 15 January, 2015) 